\title{
The Effect of Circuit Training on Aerobic Fitness and Body Fat Percentage
}

\author{
Presto Tri Sambodo \\ Master Program in Sport Sciences \\ Yogyakarta State University \\ Yogyakarta, Indonesia \\ prestotri@gmail.com
}

\author{
Suharjana \\ Faculty of Sport Sciences \\ Yogyakarta State University \\ Yogyakarta, Indonesia \\ suharjana_pkr@uny.ac.id
}

\author{
Galih Yoga Santiko \\ Master Program in Sport Sciences \\ Yogyakarta State University \\ Yogyakarta, Indonesia \\ galih24_sport.2017@student.uny.ac.id
}

\begin{abstract}
-having an ideal body shape is the desire of everyone, both young and old. The purpose of this study was to determine (1) the effect of block circuit training on aerobic fitness and body fat percentage, (2) the effect of non-block circuit training on aerobic fitness and body fat percentage, and (3) differences in the effect of exercise on block and non-circuit training block against aerobic fitness and body fat percentage. This research is an experimental research and as a result of this made use of pre-test post-test design two groups design as its research design method. The population in this study were 57 members of fat loss at GOR UNY Fitness Center. Purposive random sampling method was used and as a result of this, 20 people were sampled. Rockport test $(1.6 \mathrm{KM})$ and body fat percentage with a scale of Bioelectrical Impedance Analysis Omron (BIA) were used as instruments. The result of this research showed that the circuit training between block and nonblock has a significant effect on aerobic fitness and body fat percentage and that differences in the effect of circuit training between blocks and non-blocks is more influential on aerobic fitness than the percentage of body fat.
\end{abstract}

Keywords--circuit training, aerobic fitness, body fat percentage

\section{INTRODUCTION}

In this era, the development of knowledge and technology has made it easy for humans to do everything quickly, easily and in lightweight. An example of this can be seen in technology that makes motorized vehicles, from the positive side, it makes long distance journeys easier and faster, but on the negative side, the vehicle is used when aiming close. Another example is the online shopping system where everything can be obtained from the click of the mouse. The negative effect of this is that it makes people become lazy and lacking in motion to the extent that the body becomes unfit, unhealthy and overweight. This makes an individual to become forgetful, weak and unable to perform certain tasks for long. In other cases, it might lead to obesity. Someone may be categorized as having obesity if such person has fat deposits between $25.1 \%-27 \%$ and severe obesity is found in people with fat deposits $>27 \%$ [6]. This leads to some psychological conditions such as lack of confidence and some physiological effects such as coronary heart disease, hypertension, diabetes etc.

One way to overcome this is by exercising regularly. Sporting activity is a necessity, both at young and old age (elderly). Exercise has many benefits including healthy body, fitness and an ideal body. [3] Generally, people are said to be healthy if they are fit and free from diseases and in some other cases it is defined as the ability to perform activities effectively without causing significant fatigue. Fitness can, therefore, be attained by visiting fitness centers. This is a place that can help in making the body become healthy, fit and ideal through weight training. [4] says weight training (WT) is an exercise that uses a tool in the form of a load that is carried out systematically within a certain period and intensity for the purpose of increasing the ability of muscle quality, power, strength, muscle endurance, muscle enlargement, tightening, weight loss, to prevent injury and to improve overall health and support physical appearance.

Weight training has several training systems that can be used including circuit training between blocks and non-blocks. Block circuits are exercises that give a load to a certain group of muscles which are done with a load or no load in several sets and repetition in sequence until it is completed which is interspersed with rest after which there is movement to another muscle group or other device. Block circuits [5] exercises help in the repeated contraction of muscle fibers so that they need a sustainable supply of energy. Non-block circuits are exercises consisting of many posts/stations ranging from 8-12 posts which are done alternately by completing one set in the initial post and then move to the next post with a short rest interval so that it becomes a series called a circuit or set. The benefit of non-block circuits exercises is that they train both the muscular and cardiorespiratory systems [6]. The training system in this study used a maximum intensity of $65 \%-75 \%$ [3] and an implementation time of 6 weeks [2]. The results of the study [7] showed that the biomotor component strength would increase by $19 \%$ after 3 weeks of exercise, $27 \%$ after 6 weeks of exercise and $38 \%$ after 10 weeks of exercise.

Therefore, these two weight training systems are very suitable for the improvement of aerobic fitness and decrease of body fat percentage.

\section{LITERATURE REVIEW}

Training is usually defined as systematic process of repeated and progressive exercises with the ultimate goal of improving athletic performance [2]. This means that training is a systematic process that is carried out repeatedly, progressively and has a purpose to improve physical appearance. In other words, training can be said to be a process that is systematic, planned, programmed, measured and organized with a goal to improve the ability, skills, and physical appearance in exercise. One of the examples of practice, whether derived from the word practice, exercise or training, is weight training. Weight training (WT) is an exercise that uses 
a tool in the form of a load that is carried out systematically within a certain period and intensity to increase the ability of muscle quality, power, strength, muscle endurance, muscle enlargement, tightening, weight loss, prevent injury, improve overall health and support physical appearance [5].

There are 3 principles of exercise [7].

1. The overload principle. This means that loading in training must be heavier than the ability that is usually overcome.

2. The principle of specificity. The exercise must lead to functional changes. The principle of specificity involves the specificity of the muscle group or the energy system that will be developed. The exercises chosen must be in accordance with the objectives to be achieved.

3. The principle of reversibility. Fitness that has been achieved gradually decreases and can even disappear altogether, if there is no consistent training. Muscle quality will decrease again if it is not regularly and continuously trained. Therefore exercise routines have an important role in maintaining fitness that has been achieved.

Set system training method is a training method that provides loading on certain groups of muscles with a load or no load in several sets and repetition in sequence, interspersed with recovering or resting after a new move to another muscle group. The block system or set system is part of series of exercises consisting of several different forms of training [8].

Fitness is physical fitness which include the ability of a person to be able to perform daily work efficiently without excessive fatigue arising so that they can still enjoy their free time [4]. Aerobic fitness is defined as the maximum capacity to inhale, distribute and use oxygen. Aerobic fitness benefits include increase in calorie expenditure, increase in fat metabolism, increases in fat utilization, reduction of lipid in the blood, and increase in non-fat tissue (muscle) [6].

The first step of fat energy metabolism is through the process of breaking down the fat deposits contained in the body, namely triglycerides. Triglycerides in the body will be stored in adipose tissue and in muscle cells (intramuscular triglycerides). Through a process called lipolysis, these stored triglycerides will be converted to fatty acids and glycerol, while the fatty acids that are formed will be broken down into small units through a process called $\beta$-oxidation to produce energy (ATP) in the mitochondria of cells. The $\beta$-oxidation process runs with oxygen and requires carbohydrates to improve the process of burning fatty acids [4].

Overweight is having excess weight over the ideal body weight composition. The excess weight that is imposed is fat deposits with a percentage of BMI ranging from $25 \%-27 \%$. The normal body fat for adult man is $15-20 \%$ of body weight, while for woman is $20-25 \%$ of body weight.

\section{MATERIALS \& METHOdOLOGY}

This study used an experimental method through the use of pretest posttest two groups research design. In this study, the independent variables are block and non-block circuit, while the dependent variable is aerobic fitness and body fat percentage

Furthermore, the research design conducted by the researcher is described in more detail in Table 1 as follows:
TABLE I. RESEARCH DESIGN FRAMEWORK

\begin{tabular}{|c|c|c|}
\hline Initial test (T1) & Treatment (P) & Final test (T2) \\
\hline \multirow{2}{*}{$\begin{array}{l}\text { Aerobic Fitness and } \\
\text { Body Fat Pesentage }\end{array}$} & (A) & $\begin{array}{l}\text { Aerobic Fitness and } \\
\text { Body Fat Pesentage }\end{array}$ \\
\cline { 2 - 2 } & (B) \\
\hline
\end{tabular}

Information:

T1: $\quad$ Initial test to describe aerobic fitness and body fat percentage.

T2: $\quad$ Final test to show the results of aerobic fitness and body fat percentage.

P (A): $\quad$ Treatment of Block Circuit groups

P (B): $\quad$ Treatment of Non-Block Circuit groups

This research was conducted between March and April 2018 at the Fitness Center, GOR FIK UNY. Exercise was carried out for 18 meetings with exercise frequency of 3 times a week. The population used in this study was 57 members of fat loss at GOR UNY Fitness Center. The sample used in this study was determined by purposive sampling with a sample of 20 people.

Data collection techniques in this study was done by giving initial tests and final tests before and after treatment respectively. The instrument used in this study for aerobic fitness using Rockport test and body fat percentage test was Bioelectrical Impedance Analysis Omron (BIA) scales.

SPSS 20 for Windows was the data analysis technique employed in this research. Hypothesis testing was done with the use of t-test analysis (paired sample t test) at a significant level of $5 \%$ or 0.05 . Before the analysis of the data, a prerequisite test consists of data normality test using Kolmogrov Smirnov and Levene Statistic homogeneity test with probability values $(\mathrm{p}>0.05)$ was carried out.

\section{RESULTS AND DISCUSSION}

\section{A. Data Description}

This research was conducted at the GOR UNY fitness center. The 20 people sampled were divided into two groups, namely block circuit groups and non-block circuit groups.

The following are the descriptive results of the research data presented in the form of tables, among others:

TABLE II. DESCRIPTIVE STATISTICS ON THE RESULTS OF AEROBIC FITNESS PRETEST AND POSTTEST AND BODY FAT PERCENTAGE.

\begin{tabular}{|l|l|l|l|l|}
\hline \multirow{2}{*}{ Treatment } & Statistic & $\begin{array}{l}\text { Pre- } \\
\text { Test } \\
\text { Result }\end{array}$ & $\begin{array}{l}\text { Post- } \\
\text { Test } \\
\text { Result }\end{array}$ & $\begin{array}{l}\text { Improvement } \\
\text { (\%) }\end{array}$ \\
\hline \multirow{2}{*}{$\begin{array}{l}\text { Circuit Block } \\
\text { Method }\end{array}$} & Total & 267 & 279 & \\
\cline { 2 - 5 } & Average & 26,7 & 27,9 & $1,2(4,49 \%)$ \\
\cline { 2 - 5 } & SD & 1,63 & 2,23 & \\
\hline \multirow{3}{*}{$\begin{array}{l}\text { Circuit Non- } \\
\text { Block }\end{array}$} & Total & 266 & 316 & \\
\cline { 2 - 5 } & Average & 26,6 & 31,6 & $5(18,79 \%)$ \\
\cline { 2 - 5 } & SD & 1,17 & 1,34 & \\
\hline
\end{tabular}

The result shows that (1) the block circuit training group before exercise was found to have an average of 26.7 and after treatment, it was found to have increased to 27.9 so that the increase in aerobic fitness in the block circuit training group was $1.2(4,49 \%)$; (2) the non-block circuit training group before 
exercise was found to have an average of 26.6 and after treatment, it was found to have increased to 31.6 so that the increase in aerobic fitness in the non-block circuit training group was $5(18.79 \%)$. Statistical results of the pretest and posttest data on fat percentage are described as follows:

TABLE III. Statistical DESCRIPTION OF THE PRETEST AND POSTTEST DATA ON THE PERCENTAGE OF FAT.

\begin{tabular}{|l|l|l|l|l|}
\hline \multirow{2}{*}{ Treatment } & Statistic & $\begin{array}{l}\text { Pre- } \\
\text { Test } \\
\text { Result }\end{array}$ & $\begin{array}{l}\text { Post- } \\
\text { Test } \\
\text { Result }\end{array}$ & $\begin{array}{l}\text { Improvement } \\
\mathbf{( \% )}\end{array}$ \\
\hline \begin{tabular}{l} 
Circuit $\begin{array}{l}\text { Block } \\
\text { Method }\end{array}$ \\
\multirow{2}{*}{$\begin{array}{l}\text { Circuit Non- } \\
\text { Block }\end{array}$}
\end{tabular} & Total & 320,4 & 292,9 & \\
\cline { 2 - 5 } & Average & 32,04 & 29,29 & $2,75(8,58 \%)$ \\
\cline { 2 - 5 } & Total & 4.07 & 3,90 & \\
\cline { 2 - 5 } & Average & 331,2 & 251,6 & \\
\cline { 2 - 5 } & SD & 4,27 & 25,16 & $7,96(24,03 \%)$ \\
\hline
\end{tabular}

The result shows that (1) the block circuit training group before exercise was found to have an average of 32.04 and after treatment, it was found to have decreased to 29.29 so that the decrease in fat percentage in the block circuit training group was $2.75(8.58 \%)$; (2) the non-block circuit training group before was found to have an average of 33.12 and after treatment, it was found to have decreased to 25.16 so that the decrease in fat percentage in the non-block circuit training group was $7.96(24.03 \%)$.

\section{B. Prerequisite Test}

The normality test used was the Kolmogrov Smirnov method. The normality test in each group was done using SPSS 20 program with a significance level of $5 \%$ or 0.05 . The following is the results of the normality test obtained:

TABLE IV. NORMALITY TEST

\begin{tabular}{|l|l|l|l|}
\hline Group & p & Sig & Information \\
\hline \multicolumn{4}{|c|}{ Block Circuit Exercise Group } \\
\hline Pretest aerobic fitness & 0.092 & 0,05 & Normal \\
\hline Posttest aerobic fitness & 0,156 & 0,05 & Normal \\
\hline Pretest Fat presentation & 0,383 & 0,05 & Normal \\
\hline Posttest Fat presentation & 0,595 & 0,05 & Normal \\
\hline
\end{tabular}

\begin{tabular}{|l|l|l|l|}
\hline Group & p & Sig & Information \\
\hline \multicolumn{4}{|c|}{ Block Circuit Exercise Group } \\
\hline Pretest aerobic fitness & 0,124 & 0,05 & Normal \\
\hline Posttest aerobic fitness & 0,017 & 0,05 & Normal \\
\hline Pretest Fat presentation & 0,210 & 0,05 & Normal \\
\hline Posttest Fat presentation & 0,732 & 0,05 & Normal \\
\hline
\end{tabular}

Based on the table above, all the values of aerobic fitness data and pretest fat percentage and posttest that have been tested for normality show a significance value of $p>0.05$, which means that the data is normally distributed.

The homogeneity test in this study was carried out using the Levene Statistics method with a significance level of 5\% or 0.05 . The following shows the homogeneity test results obtained:

TABLE V. Homogeneity Test Results

\begin{tabular}{|l|l|l|l|l|l|}
\hline Group & Levene Statistics & df1 & df2 & sig & Information \\
\hline $\begin{array}{l}\text { Aerobic } \\
\text { Fitness }\end{array}$ & 1,565 & 1 & 18 & 0,227 & Homogene \\
\hline Fat & 0,984 & 1 & 18 & 0,334 & Homogene \\
\hline
\end{tabular}

The result shows that on aerobic fitness, a significance value of $0.227>0.05$ was obtained. This means that the data group has a homogeneous variant. Likewise, the results of the calculation of fat obtained a significance value of $0.334 \geq 0.05$. This means that the group has a homogeneous variant. Thus the population has a homogeneous variant.

\section{Hypothesis Test Results}

1. Block Circuit Exercise Group on Aerobic Fitness and Fat Percentage.

TABLE VI. Test of Pretest Result and Postest of Block CIRCUIT EXERCISE GROUPS

\begin{tabular}{|l|l|l|l|l|l|}
\hline Variable & Mean & T ht & Sig, & Dispute & \% \\
\hline $\begin{array}{l}\text { Aerobic } \\
\text { Fitness }\end{array}$ & 26,70 & 3,34 & 0,009 & 1,2 & $4,49 \%$ \\
\cline { 2 - 4 } $\begin{array}{l}\text { Fat } \\
\text { Presentation }\end{array}$ & 27,90 & & & & \\
\cline { 2 - 3 } & 29,29 & 9,35 & 0,000 & 2,75 & $8,58 \%$ \\
\hline
\end{tabular}

Based on the results of the T-test in the table above, it can be seen that for aerobic fitness, $\mathrm{T}$ counts was 3.34 with a significance value of $p$ at 0.009 , while for the percentage of fat $\mathrm{T}$ counts was 9.35 with a significance value of $\mathrm{p}$ at 0.000 . Because each significance value of $p<0.05$, this result shows that there are significant differences. Thus, the hypothesis that there is a significant effect of block circuit training on aerobic fitness and fat percentage has been proven.

\section{Group Training of Non-Block Circuits on Aerobic Fitness and Fat Percentage.}

TABLE VII. TEST OF PRETEST AND POSTTEST RESUlts FOR NONBLOCK CIRCUIT TRAINING GROUPS

\begin{tabular}{|l|l|l|l|l|l|}
\hline Variable & Mean & T ht & Sig, & Dispute & \% \\
\hline $\begin{array}{l}\text { Aerobic } \\
\text { Fitness }\end{array}$ & 26,60 & 15,00 & 0,000 & 5,0 & $18,79 \%$ \\
\cline { 2 - 6 } $\begin{array}{l}\text { Lemak } \\
\text { Presentation }\end{array}$ & 31,60 & & & & \\
\cline { 2 - 6 } & 25,16 & 12,79 & 0,000 & 7,96 & $24,03 \%$ \\
\hline
\end{tabular}

Based on the results of the T-test in the table above, it can be seen that for aerobic fitness, $\mathrm{T}$ count was 15.00 with a significance value of $\mathrm{p}$ at 0,000 , while for the percentage of fat, $T$ count was 12.79 with a significance value of $p$ at 0.000 . Because each significance value of $\mathrm{p}<0.05$, this result shows that there are significant differences. Thus, the hypothesis that there is a significant effect of non-block circuit training on aerobic fitness and fat percentage has been proven.

3. Differences in the Effect of Circuit Exercise Groups Between Blocks and Non Blocks on Aerobic Fitness and Fat Percentage

TABLE VIII. TEST RESULTS OF CIRCUIT EXERCISE GROUPS BETWEEN BLOCKS AND NON BLOCKS

\begin{tabular}{|c|c|c|c|c|c|}
\hline Variable & Mean & T ht & Sig, & Dispute & $\%$ \\
\hline \multirow{2}{*}{$\begin{array}{l}\text { Aerobic } \\
\text { fitness }\end{array}$} & 1,2 & \multirow{2}{*}{4,48} & \multirow{2}{*}{0,000} & \multirow{2}{*}{3,8} & $4,49 \%$ \\
\hline & 5,0 & & & & $18,79 \%$ \\
\hline Presentation & 2,75 & \multirow{2}{*}{2,54} & \multirow{2}{*}{0,020} & \multirow{2}{*}{5,21} & $8,58 \%$ \\
\hline Fat & 7,96 & & & & $24,03 \%$ \\
\hline
\end{tabular}

Based on the results of the T-test in the table above, it can be seen that for aerobic fitness, $\mathrm{T}$ counts was 4.48 with a significance value of $\mathrm{p}$ at 0.000 , while for the percentage of 
fat, $\mathrm{T}$ counts was 2.54 with a significance value of $\mathrm{p}$ at 0.020 . Because each significance value of $\mathrm{p}<0.05$, this result shows that there is a significant difference in circuit training between blocks and non-blocks on aerobic fitness and body fat percentage. Based on the results above, it was discovered that circuit training between blocks and non-blocks has more influence on aerobic fitness than the percentage of body fat. For the average data, it was discovered that aerobic fitness and fat percentage of the Non-Block Circuit exercise group is better than the Block Circuit exercise group.

\section{a. Effect of Block Circuit Exercise on Aerobic Fitness and Fat Percentage.}

As physiological adaptation occurs, weight training also causes physical adaptation. Weight training, in addition to building strength, can also improve fitness and reduce fat. Aerobic exercises predominantly increase aerobic capacity, myoglobin, cell mitochondria (number and size), and muscle glycogen reserves, and increase the concentration of oxidative enzymes [1]. On the other hand, anaerobic exercises are more dominant in increasing anaerobic capacity, ATP-PC energy system and anaerobic glycolysis [7]. The system set method can be applied in various forms of program variations in exercise, repetition, set or rest so that it does not only increase muscle mass but also improve aerobic fitness and reduce fat percentage. This is evidenced by the results of research that says that there are significant results of exercise using block circuits on physical fitness and fat percentage.

\section{b. Effect of Non-Block Circuit Exercises on Aerobic Fitness and Fat Percentage}

Improvement of aerobic fitness explained that based on research [3], low intensity circuit weight training exercises $(60 \%-70 \%)$ result in an increase of $38.50 \%$, with a fast rhythm so that it could increase heart rate up to $77.6 \%$ DJM, which included zones heart endurance intensity as recommended [5]. Exercise at this intensity stimulates the cardiorespiratory system which has an impact on increasing blood circulation, heart rate, stroke volume, and cardiac ouput. Exercises in the fat burning zone range from $65 \%-75 \%$ DJM which stimulates the secretion of epinerfin hormone secreted by the adrenal glands in the sympathetic nerve endings. The epinerfin hormone reacts to the beta receptors found in adipose tissue then activates adenyl cyclase which acts to break ATP into AMP cyclis and together with lipase breaks trigleserides into FFA (free fat acid) and glycerol, then enter the kreb cycle to produce energy, this will have an impact on reduction of body fat [3].

c. Differences in the effect of circuit training between blocks and non-blocks on aerobic fitness and fat percentages

As stated earlier, aerobic exercises predominantly increase aerobic capacity, myoglobin, cell mitochondria (number and size), and muscle glycogen reserves, and increase the concentration of oxidative enzymes. Aerobic exercise can also increase the number and size of muscle twitch fiber, while the anaerobic exercises will increase the number and size of fast twitch fiber muscles.

Aerobic exercise that reaches the intensity zone of cardiac endurance stimulates the cardiorespiratory system so that it has an impact on improving blood circulation, heart rate, stroke volume, and cardiac ouput [5]. For aerobic exercise that falls into the fat burning zone, according to Coker (1992: 10) cited in [3], ranging from $65 \%-75 \%$ DJM so that it stimulates the secretion of epinerfin hormone in order to increase the sensitivity of cell membrane receptors to activate the lipase enzyme. The presence of this enzyme will increase lipolysis which is the division of trigosteride molecules into fatty acids and glycerol which then enter the kreb cycle to produce energy. Consequently, it has an impact on fat reduction in adipose tissue.

\section{CONCLUSION}

Based on the results of the study and the results of data analysis that has been carried out, the following conclusions are obtained:

a. There is a significant effect of block circuit training on aerobic fitness and body fat percentage for people with overweight.

b. There is a significant effect of non-block circuit training on aerobic fitness and body fat percentage for people with overweight.

c. There is a significant difference in the effect of circuit training between blocks and non-blocks on aerobic fitness and body fat percentage for people with overweight.

Non-block circuit training is better than block circuit training on aerobic fitness and fat percentage.

\section{REFERENCES}

[1] H. B. Bafirman, "Kontribusi fisiologi olahraga mengatasi resiko menuju prestasi optimal," Jurnal media ilmu keolahragaan indonesia. Vol, 3, No1, 1-70. http://journal.unnes.ac.id/nju/index.php.miki, 2013.

[2] T. O. Bompa, "Theory and methodologi of training," Toronto. Kendal/Hunt Publishing Company, 2015.

[3] D. P. Irianto, "Dasar-dasar latihan kebugaran," Yogyakarta. FIK UNY, 2004.

[4] D. P. Irianto, Peranan joging dan circuit weight training pada profil lemak tubuh dan kebugaran aerobic penyandang overweight," Disertasi. UNESA. Surabaya, 2009.

[5] A. Setiawan, "Pengaruh latihan beban metode compound set dan cirkuit training terhadap persentase lemak tubuh ditinjau dari volume oksigen maksimum (vo2max)," Tesis, UNY. Yogyakarta, 2018.

[6] J. B. Sharkey, "Kebugaran dan Kesehatan," Jakarta. PT. RajaGrafindo Persada. 2011.

[7] Suharjana. "Kebugaran jasmani," Yogyakarta.Jogja Global Media, 2013.

[8] Sukadiyanto \& Muluk. "Pengantar teori dan metodologi melatih fisik," Bandung. Lubuk Agung, 2011.

[9] T. O. Bompa, "Theory and methodology of training (terjemahan)," Bandung: UNPAD, 1994. 